\title{
The influence of milk withdrawal, stable routines and separation from dam on suckling behaviour of Hereford calves
}

\begin{abstract}
The influence of milk withdrawal, stable routines and separation from dam on suckling behaviour of beef calves was tested in an 8x8 Latin square experiment. Length of the meal and length of the longest bout were measured to describe the meal as a whole. Length of pre-stimulation, increasing ejection, declining ejection, and afterstimulation were measured to describe the structure of meal. Eagerness of suckling was described as relative suckling time and non-suckling. Milk withdrawal increased length of meal and longest bout, but did not influence structure of meal. Milk withdrawal resulted in cistern-milk being available already before ejection and thereby in longer bouts during pre-stimulation. Milk withdrawal had no influence on eagerness of suckling. Stable routines had no influence on meal as a whole, but increased pre- and decreased after-stimulation and tended to result in somewhat longer bouts during pre-stimulation. There was no influence of stable routines on eagerness of suckling. Separation from dam had no influence on meal as a whole or structure of meal, but increased eagerness of suckling for the whole meal and for almost all periods. The experimental results partially sustained results from a field study.
\end{abstract}

Key Words: Beef cattle, Hereford, suckling behaviour, milk withdrawal, stable routines, separation from dam

\section{Zusammenfassung}

Titel der Arbeit: Über den Einfluss von Hunger, Stallarbeiten und Trennung von der Mutter auf das Saugverhalten von Herefordkälbern

Der Einfluss von Milchentzug, Stallroutinen und Trennung von der Mutter auf das Saugverhalten von Fleischkälbern wurde in einen 8x8 Lateinischen Quadrat untersucht. Die Mahlzeitlänge, die Länge der längsten "ununterbrochenen Saugezeit an einer Zitze" beschrieben die Mahlzeit als Ganzes. Die Länge der Vorstimulation, der steigenden Ejektion, der abnehmenden Ejektion und der Nachstimulation beschrieben die Struktur einer Mahlzeit. Der Eifer des Saugens wurde mittels relativer Saugzeit und Nichtsaugezeit beschrieben. Milchentzug erhöhte die Mahlzeitlänge und die längste ununterbrochene Saugezeit an einer Zitze, beeinflusste aber die Mahlzeitstruktur nicht. Milchentzug führte dazu, dass schon vor der Ejektion zisternale Milch vorhanden war, was seinerseits in längeren ununterbrochenen Saugezeiten an einer Zitze während der Vorstimulation resultierte. Milchentzug beeinflusste den Eifer des Saugens nicht. Stallroutinen hatten keinen Einfluss auf die Mahlzeit als Ganzes, verlängerten aber die Vor- und verkürzten die Nachstimulation. Auch zeigte sich während Stallroutinen eine Tendenz zu längeren ununterbrochenen Saugezeiten an einer Zitze während der Vorstimulation. Stallroutinen beeinflussten den Eifer des Saugens nicht. Trennung von der Mutter hatte keinen Einfluss auf die Mahlzeit als Ganzes oder die Mahlzeitstruktur, steigerte aber den Eifer des Saugens während fast aller Perioden. Die experimentellen Ergebnisse werden teilweise von denen einer Felduntersuchung unterstützt.

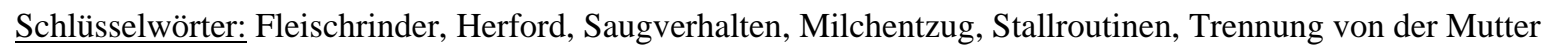

\section{Introduction}

Calf suckling behaviour was recorded within the framework of developing a physiological milk harvest process. The methodological question arose whether voluntary suckling meals are comparable with meals after separation from dam, the later ones often combined with preceding milk withdrawal and consecutive suckling 
during stable routines.

Limiting access of the calf to its dam has been studied either as a treatment (e.g., TEELUCK et al., 1981) or as part of the management system (e.g. THOMAS et al., 1981; SANDOVAL and LEAVER, 1995). Separation between offspring and mother was introduced (HORRELL, 1993; BOONBRAHM et al.; 2004) to decrease observer idle time, as offspring and mother usually start a suckling meal (referred to as meal in the following) shortly after access is granted (referred to as separation meal in the following). Separation meals often occur during stable routines (feeding, removal of manure etc.) in commercial production systems. De PASSILLÉ et al. (1992) found that stable routines failed to stimulate suckling when calves were fed from buckets with artificial teats. However, it cannot be excluded a priori that man-made activities, which act as external timers might influence suckling behaviour when a calf suckles its own dam.

Separation of closely related animals - either monogamous pairs (e.g., CASTRO and MATT, 1997) or mother and offspring - results in a form of stress (WEINER, 1992). Stress was said to inhibit oxytocin release (e.g., MIELKE, 1981; MANTEUFFEL, 2002). If stress could partially inhibit the oxytocin release it should influence suckling behaviour as well (MAYNTZ and COSTA, 1998). Spontaneous observations of separation meals gave the impression that suckling during separation meals were carried out with increased eagerness. This anthropomorphic impression contrasted with the stereotypical reaction of suckling calves confronted with artificial teats (RUSHEN and de PASSILLÉ, 1995).

Observations of calves' suckling behaviour revealed a structure of a voluntary meal, i.e., the relationship between several parts of a meal and the meal as a whole. The main parts were pre-stimulation, ejection and after-stimulation (MAYNTZ and COSTA, 1998). After-stimulation, especially, could be a part of calves' honest begging by which the offspring informs the parent about increased need (GODFRAY, 1995). Thus, milk withdrawal could enhance after-stimulation as a part of the honest begging signal in Bos taurus.

The report includes three parts shown in Table 1 . The field study revealed a lot of confounding between effects. Therefore the main experiment was designed to test the un-confounded effects.

The main objectives of the research reported here were methodological: to investigate the influence of milk withdrawal, external timers in the form of stable routines, and separation between calf and dam on variables describing the meal as a whole, the structure of meal, and the eagerness of suckling.

\section{Field Study}

\section{Materials and methods}

Animals and management. Four female and five male calves ranging in age from 64 to 70 days at the onset of recording were randomly selected from a 54-calf-dam-pairs (CDP) Hereford-herd kept on an isolated pasture from 0800 to 1800 . The selected calves and dams were clearly marked with large figures on their flanks. During the night calves and dams were kept in adjacent corrals separated by bars. Calves were offered shelter and concentrates in their corral. At 0530 a worker arrived. Calves and dams gathered along the bars between the corrals and mixed eagerly when he removed the bars. Suckling started immediately when a calf and its dam met. Thereafter the 
herd went to a nearby pasture.

This first morning meal was recorded on videotape for each of the nine selected CDPs on nine consecutive days. Recording began before the bars were removed and stopped some minutes after calf and dam had finished the meal by voluntary separation. These meals are referred to as "separation meals of young calves". The CDP recorded in the morning was focused during pasture hours that day and a voluntary afternoon meal was recorded. These meals are referred to as "voluntary meals of young calves".

Table 1

Parts of the work, objectives and treatments. vs:versus (Teile der Untersuchung, Ziele und Behandlungen)

\begin{tabular}{|c|c|}
\hline Part & Treatments \\
\hline Field study & $\begin{array}{ll}\text { Testing the spontaneous impression } & \text { Meals after } 12 \text { hours separation } \\
\text { of increased eagerness of suckling } & \text { from dam vs voluntarily initiated } \\
\text { after separation from dam } & \text { meals }\end{array}$ \\
\hline Main experiment & $\begin{array}{l}\text { Testing the influence of milk } 2 \times 2 \times 2 \text { factorial arrangement of } \\
\text { withdrawal, stable routine and three main treatment factors: milk } \\
\text { separation from dam with a withdrawal, stable routines and } \\
\text { minimum of confounding } \\
\begin{array}{l}\text { separation between dam and } \\
\text { offspring }\end{array}\end{array}$ \\
\hline Additional control experiment no. 1 & $\begin{array}{l}\text { Testing whether the control } \\
\text { treatment applied in the main } \\
\text { experiment resulted in suckling } \\
\text { behaviour different from voluntary } \\
\text { meals }\end{array}$ \\
\hline Additional control experiment no. 2 & $\begin{array}{l}\text { Testing whether separation of calf Suckling without milk withdrawal, } \\
\text { and dam with or without acoustical, not during stable routines and with } \\
\text { visual or olfactory exchange would separation from dam with vs } \\
\text { result in different effects on without acoustical, visual or } \\
\begin{array}{ll}\text { suckling behaviour. } & \text { olfactory exchange with the herd }\end{array}\end{array}$ \\
\hline
\end{tabular}

Table 2

Treatments. m: no milk withdrawal, M: milk withdrawal, r: no suckling during stable routines, R: suckling during stable routines, s: no separation, S: separation (Behandlungen. m: kein Milchhunger, M: Milchhunger, r: kein Saugen während Stallroutinen, R. Saugen während Stallroutinen, s. kein Saugen nach Trennung von der Mutter, S: Saugen nach Trennung von der Mutter)

\begin{tabular}{lcccc}
\hline Treatment & $\begin{array}{c}\text { Milk withdrawal } \\
\text { before suckling }\end{array}$ & $\begin{array}{c}\text { Suckling during stable } \\
\text { routines }\end{array}$ & $\begin{array}{c}\text { Calf and dam } \\
\text { separated before } \\
\text { suckling }\end{array}$ & $\begin{array}{c}\text { Treatment } \\
\text { abbreviation }\end{array}$ \\
\hline 1 & no & no & no & mrs $^{\mathrm{a}}$ \\
2 & yes & no & no & Mrs $^{\mathrm{b}}$ \\
3 & no & yes & no & $\mathrm{mR}^{\mathrm{b}}$ \\
5 & no & no & yes & $\mathrm{mrs}^{\mathrm{b}}$ \\
6 & yes & yes & yes & MrS \\
7 & yes & no & yes & mRS \\
\hline
\end{tabular}

${ }^{\mathrm{a}}$ Control treatment, ${ }^{\mathrm{b}}$ Pure treatments of the main treatment factors milk withdrawal, stable routines, and separation.

Five randomly selected bull-CDPs, marked with large figures on their flanks were kept in a loose housing barn with 95 other bull-CDPs. The selected calves ranged from 113 to 216 days of age at the onset of recording. The stable was divided into ten compartments containing ten CDPs each. Calves and their dams were kept in separate neighbouring sub-compartments to be able to be fed different amounts of concentrate. Doors from each sub-compartment leading to ten undivided outside runs were opened at 0630 and 1530. Dam and calves were together in those outside runs for about 1 hour twice daily while manure was removed and fresh feed distributed by tractors driving 
through the stable. The opening of the doors to the outside runs announced this activity. CDPs always initiated a meal after they had left the stable in the morning. Frequent, but not regular meals occurred in the afternoon.

During three successive days the dams were allowed to enter the outside run as usual. Calves, however, were released from the stable one by one, after each preceding one had finished the meal (morning and evening) and/or did not show any intention to initiate a meal (evening). Meals were video-recorded at the morning of the third day, representing "separation meals of old calves". Thereafter the bars between the subcompartments in the stable were removed and the doors to the outside runs left open for five days. Voluntary meals were recorded during the last two days of this period, representing "voluntary meals of old calves".

Statistics. Data were analysed by GLM procedure of SAS (SAS/STAT, 1989). The model included the effects "age" (i.e. young or old calves), "sex nested in age", "calf nested in age x sex", "type of access to dam" (i.e. separation or voluntary access and), "age x type of access". Contrasts between least-square means (LSM) were tested by Duncan's t-test.

\section{Main Experiment}

Animals and management. Eight CDPs from an 18-CDPs-Hereford-herd fulfilled the following criteria: (i) calves at least 20 days old at the onset of the experiment and (ii) dams being tolerant to handling. No further CDPs fulfilling both conditions were available. Dams in the herd were tied up but the calves could walk freely within the stable. Feeding concentrates and roughage, removing manure and refreshing straw bedding (referred to as "stable routines") occurred from 0600 to 0700 and from 1700 to 1800 . For the separation between calf and dam two separate cubicles of $9 \mathrm{~m}^{2}$ each with mangers were available in the stable about $4 \mathrm{~m}$ away from the stands of the experimental dams.

Treatments and experimental design. In the following we always use the terminology below: (i) milk withdrawal, stable routines and separation between dam and offspring are referred to as "main treatment factors", (ii) yes-no-combinations of the main treatment factors (Tab. 2) as "treatments" and (iii) a treatment that included only one main treatment factor (treatments 2 to 4 in Tab. 2) as "pure treatments". Treatment 1 (Tab. 2) that did not include milk withdrawal, or separation, and allowed suckling meals other than during stable routines was regarded as control because the calves initiated a voluntary meal at dawn, i.e. at about 0500 .

We selected an 8x8 Latin square as experimental design (i) to get sufficient number of replications for each treatment despite the limited number of CDPs and (ii) to balance the nuisance effects "animal" and "period". One experimental unit consisted of one CDP and three days. On day 3 the management procedure conventionally used in that stable was applied to avoid carry-over effects.

Not letting the calf suckle for $18 \mathrm{~h}$ is referred to as "milk withdrawal”. An 18-h-period was chosen because Hereford calves of that age had not suckled voluntarily during up to $14 \mathrm{~h}$ (MAYNTZ, unpublished data). Hay was given to the calves at the beginning of such milk withdrawal, however, not ad libitum. That could be judged because there was no hay left in the separation box after the 18-h-period.

Carrying through. Cross suckling from all calves with almost all dams was common in the herd. Therefore the udders of all experimental dams had to be covered by a tailor- 
made net during the treatment days. Furthermore, experimental calves had to be prevented from suckling the non-experimental dams tied up at the opposite side of the feeding aisle by separating this part of the stable. Two observers recorded independently of each other. Recording was activated together with the removal of the udder net and continued until some minutes after calf and dam had finished the meal by voluntary separation.

Statistics. Data were analysed by GLM procedure of SAS (SAS/STAT, 1989). The model included the effects "CDP", "period" and "treatment". Contrasts between LSM were tested by Duncan's t-test. One missing experimental unit was replaced using the procedure given by COCHRAN and COX (1957).

Four pairs of treatments were compared within each main treatment factor. The actual treatments within each of these pairs differed with regards to the actual main treatment factor only. Capitals symbolize the presence of a main treatment factor (e.g., $\mathrm{M}=$ milk withdrawal) and small letters the absence (e.g., $\mathrm{m}=$ no milk withdrawal) within a treatment. Thus, the four comparisons concerning the influence of e.g., the main treatment factor "milk withdrawal" were: (i) "Suckling meal after milk withdrawal, not during stable routines and without separation" (treatment 2 or pure treatment of milk withdrawal in Tab. 2) versus (vs) "suckling meal not after milk withdrawal, not during stable routines and without separation" (treatment 1 or control in Tab. 2); in abbreviation Mrs vs mrs. The remaining three comparisons were: MRs vs mRs, MrS vs $\mathrm{mrS}$, and MRS vs mRS. A significant influence of a main treatment factor on the examined variable was assumed when significant and similar contrasts were found in one of the following three cases: (i) in the first comparison that included the pure treatment (e.g., Mrs vs mrs) and at least one of the remaining three comparisons or (ii) in all three comparisons that did not include the pure main treatment parameter (e.g., MRs vs mRs, MrS vs mrS, and MRS vs mRS) and (iii) in all four comparisons.

\section{Additional Control Experiments}

Animals and management. Two groups of four different CDPs were selected from those dams that were not involved in the main experiment. The groups were assigned to two different objectives: (i) the "control of the control treatment" and (ii) the "control of the type of separation" applied in the main experiment. Each calf was at least 16 days old.

Treatments and recording. In the first group, voluntary meals, which did not occur during stable routines, were recorded at day 11 of the main experiment. The observer interfered only to prevent cross suckling of the recorded calf at a foreign dam or of an alien calf at the recorded dam during that meal. These meals are referred to as "control of control meals". The four control of control meals were pooled with those four repetitions of control meals in the main experiment (treatment 1 in Tab. 2) that had occurred during the first four periods of the main experiment.

Two calves of the second group were transported about $600 \mathrm{~m}$ away behind a hill from where no acoustical, visual or olfactory exchange with the herd was possible. They were transported in a closed animal van at 0700 after the voluntary morning meal. Four hours later they were transported back to the stable and immediately brought to their dams where the next meal was recorded. Rules for observer interference were the same as for the control of control meals. This procedure was carried out at day 17 and 23 of the main experiment. These meals are referred to as "control of type of separation meals". The control of type of separation meals were pooled with those four 
repetitions of pure treatment of separation, (treatment 4 in Tab. 2) which had occurred in the last four periods of the main experiment.

Statistics. Data were analysed by GLM procedure of SAS (SAS/STAT, 1989). The model included the effects "animal" and "treatment".

\section{Data-Handling and definitions}

A time code was copied on the videotapes, allowing different activities to be separated with an accuracy of 0.04 seconds. A bout started with the first contact of the calf's mouth at a specific teat but continued until the first contact at a new teat or the renewed contact at the same teat after an interruption of suckling.

\section{Variables}

Tab. 3 summarises the variables. The structure of meal was described by the length of the four distinguishable periods (Fig. 1): "pre-stimulation" (AB),"increasing ejection" (BC), "declining ejection" (CD) and "after-stimulation" (DE). These periods were expressed in seconds and \% of length of meal, referred to as e.g., $\mathrm{AB}_{\mathrm{s}}$, or $\mathrm{AB}_{\%}$.

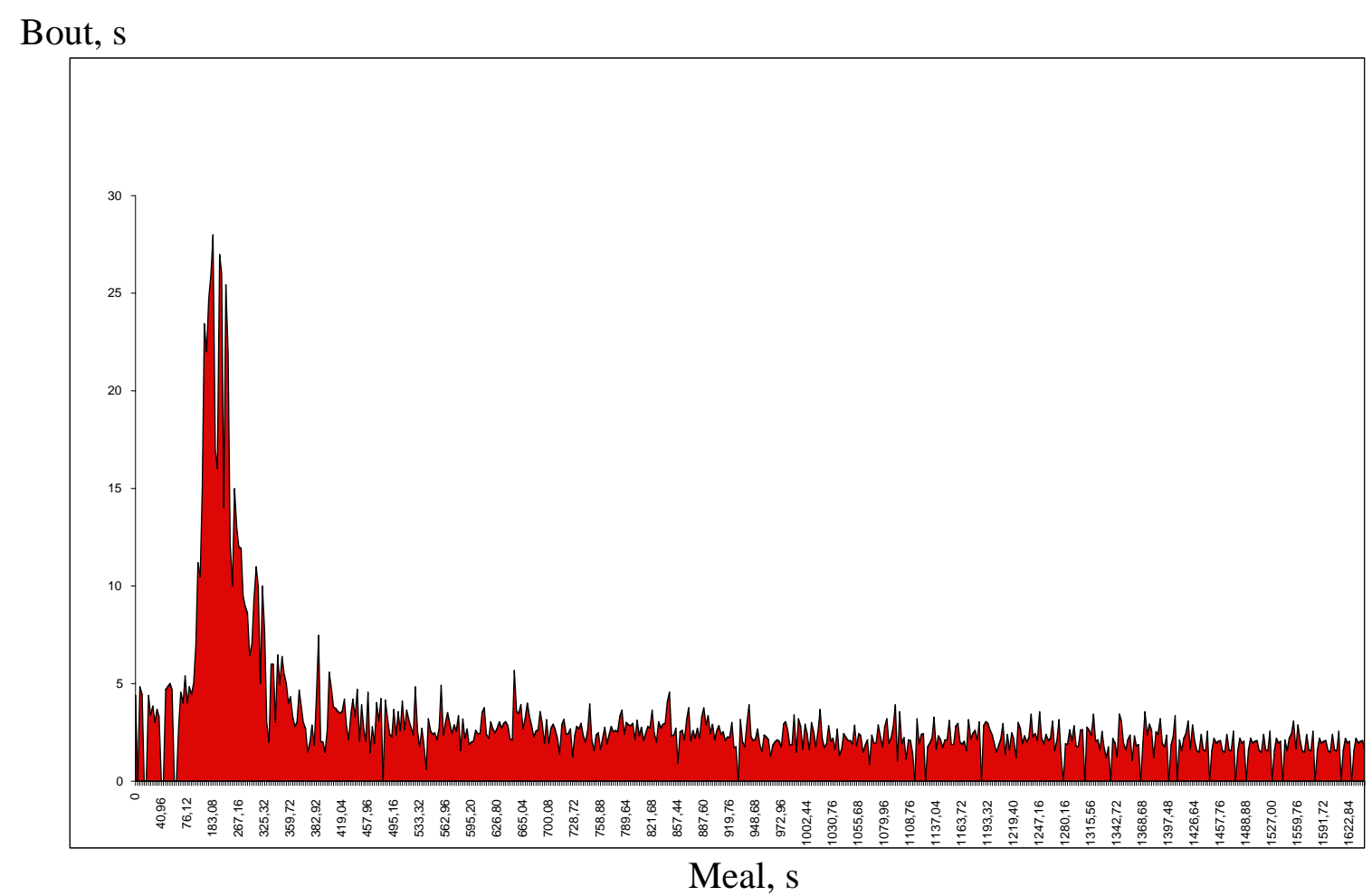

A BC D

$\mathrm{E}$

Fig. 1: Periods of a control suckling meal. (AB): pre-stimulation, (BC): increasing ejection, (CD): declining ejection, (DE): after-stimulation (Phasen eines Kontrollmals. (AB): Vorstimulation, (BC): zunehmende Ejektion, (CD): abnehmende Ejektion, (DE): Nachstimulation)

The length of the periods mentioned above were calculated in the following way: A (start of the meal) and $\mathrm{E}$ (end) were given as well as the starting time of the longest bout, representing point $\mathrm{C}$. A series of bouts of increasing length preceding point $\mathrm{C}$ were submitted to a linear regression (no. 1) with the starting times of those bouts as the independent variable and their length as the dependent variable. To produce regression no. 2, the procedure was repeated with all remaining bouts between $\mathrm{A}$ and C. The crossing point of both regressions gave the calculated point B. Thereafter point 
D was calculated in an equivalent way. In most cases the calculated points B and/or D did not coincide with the start of a bout. Then the start of the bout closest to the calculated point B and/or D was chosen.

Meals after milk withdrawal (referred to as "milk withdrawal meals") presented an unforeseen problem. The very long bouts during AB (Fig. 2) sometimes resulted in not being able to calculate a point $\mathrm{B}$ as described above. In these cases the start of the shortest bout within a drop in the bouts before point $C$ (Fig. 2) was accepted as point B. $A B_{s}$ and $A B_{\%}$ of meals with short (Fig. 1) and long bouts during $A B$ (Fig. 2) showed no conclusive differences after evaluation.

Table 3

Variables used in the different parts (Variable der verschiedenen Untersuchungsteile)

\begin{tabular}{|c|c|c|c|}
\hline Trait & Variable & Definition and / or dimension & Used in part \\
\hline $\begin{array}{l}\text { Meal as a } \\
\text { whole }\end{array}$ & $\begin{array}{l}\text { Length of longest } \\
\text { bout }\end{array}$ & {$[\mathrm{s}]$} & $\begin{array}{l}\text { - Field study } \\
\text { - Main experiment } \\
\text { - Additional control experiments } \\
\text { - Field study } \\
\text { - Main experiment } \\
\text { - Additional control experiments }\end{array}$ \\
\hline \multirow[t]{5}{*}{$\begin{array}{l}\text { Meal } \\
\text { structure }\end{array}$} & Pre-stimulation & $\begin{array}{l}\text { Initial period of short or long bouts } \\
\text { before ejection; [s], [\% of meal] }\end{array}$ & $\begin{array}{l}\text { - Field study [s] only } \\
\text { - Main experiment } \\
\text { - Additional control experiments }\end{array}$ \\
\hline & Increasing ejection & $\begin{array}{l}\text { Period of increasing bouts after } \\
\text { ejection; [s], [\% of meal] }\end{array}$ & $\begin{array}{l}\text { - Field study [s] only } \\
\text { - Main experiment } \\
\text { - Additional control experiments }\end{array}$ \\
\hline & $\begin{array}{l}\text { Decreasing } \\
\text { ejection }\end{array}$ & $\begin{array}{l}\text { Period of decreasing bouts after } \\
\text { increasing ejection; [s], [\% of meal] }\end{array}$ & $\begin{array}{l}\text { - Field study [s] only } \\
\text { - Main experiment } \\
\text { - Additional control experiments }\end{array}$ \\
\hline & After-stimulation & $\begin{array}{l}\text { Final period of short bouts after } \\
\text { decreasing ejection; [s], [\% of meal] }\end{array}$ & $\begin{array}{l}\text { - Field study [s] only } \\
\text { - Main experiment } \\
\text { - Additional control experiments }\end{array}$ \\
\hline & Ejection & $\begin{array}{l}\text { Increasing + decreasing ejection; } \\
{[\mathrm{s}],[\% \text { of meal }]}\end{array}$ & $\begin{array}{l}\text { - Field study [s] only } \\
\text { - Main experiment } \\
\text { - Additional control experiments }\end{array}$ \\
\hline \multirow[t]{2}{*}{ Eagerness } & $\begin{array}{l}\text { Relative suckling } \\
\text { time }\end{array}$ & $\begin{array}{l}=(\Sigma \text { undoubted possible suckling } \\
\text { time / length of meal) x } 100 \text {. } \\
\text { Undoubted possible suckling time = } \\
\text { periods, during which the teat was } \\
\text { stretched in the calf's mouth and the } \\
\text { calf practicing sucking movements } \\
\text { (HALL et al., 1988) }\end{array}$ & $\begin{array}{l}\text { - Field study } \\
\text { - Main experiment } \\
\text { - Additional control experiments }\end{array}$ \\
\hline & $\begin{array}{l}\text { Arithmetic mean } \\
\text { of non-suckling } \\
\text { per bout for whole } \\
\text { meal and each } \\
\text { period }\end{array}$ & $\begin{array}{l}\text { Non-suckling per bout = bout - } \\
\text { undoubted possible suckling time }\end{array}$ & $\begin{array}{l}\text { - Main experiment } \\
\text { - Additional control experiments }\end{array}$ \\
\hline $\begin{array}{l}\text { Distinguish } \\
\text { pre- } \\
\text { stimulation } \\
\text { with short } \\
\text { and long } \\
\text { bouts }\end{array}$ & $\begin{array}{l}\text { Relative number of } \\
\text { bouts within pre- } \\
\text { stimulation }\end{array}$ & $\begin{array}{l}\mathrm{n}_{\text {bout }} \text { within pre-stimulation / pre- } \\
\text { stimulation }\end{array}$ & $\begin{array}{l}\text { - Main experiment } \\
\text { - Additional control experiments }\end{array}$ \\
\hline
\end{tabular}

It was unsatisfying to be unable to distinguish between these two different types of appearance of $\mathrm{AB}$. Thus we introduced an additional variable "relative number of bouts within $\mathrm{AB} "$. 
Bout, $s$

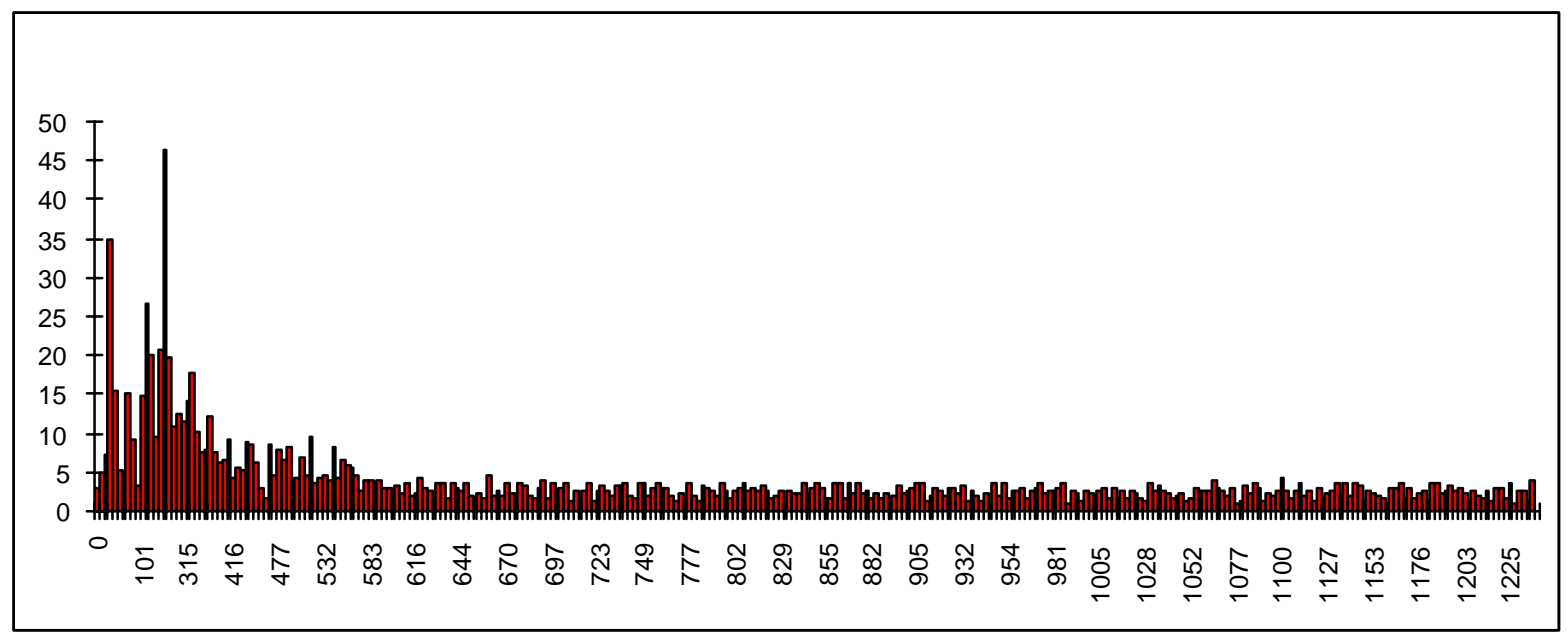

Meal, s

ABC D

Fig. 2: Example of a suckling meal after milk withdrawal (Beispiel eines Mahls nach Milchhunger)

Table 4

Least-square means (LSM) and contrasts of the variables significantly effected by "age x type of access" and levels of significance (P) of the contrast between separation and voluntary meals ${ }^{+}$(Least-square means (LSM) und Kontraste der Variablen, die durch den Effekt "Alter x Art des Zugangs zur Mutter" beeinflusst wurden, sowie die Wahrscheinlichkeit (P) der Kontraste zwischen Malzeiten nach Trennung und freiem Zugang zur Mutter)

\begin{tabular}{|c|c|c|c|c|c|c|}
\hline Variable & VMY & SMY & $\mathrm{P}$ & VMO & SMO & $\mathrm{P}$ \\
\hline Meal length $_{\mathrm{s}}$ & 522.94 & 898.83 & 0.0022 & 783.54 & 737.88 & n. s. \\
\hline Longest bout $_{\mathrm{s}}$ & 21.08 & 50.11 & 0.0191 & 13.68 & 54.67 & 0.0066 \\
\hline $\mathrm{RST}_{\%}$ & 72.72 & 77.1 & 0.0904 & 70.14 & 85. 73 & 0.0001 \\
\hline Pre-stimulation $_{\mathrm{s}}$ & 49.81 & 0.45 & 0.0133 & 49.15 & 11.88 & 0.0628 \\
\hline Ejection $_{\mathrm{s}}$ & 164.03 & 389.03 & 0.0001 & 228.54 & 275.29 & n. s. \\
\hline After-stimulation $_{\mathrm{s}}$ & 238.07 & 487.32 & 0.0188 & 462.68 & 461.31 & n. s. \\
\hline
\end{tabular}

${ }^{+} \mathrm{VMY}=$ voluntary meals of young calves, SMY = separation meals of young calves, VMO = voluntary meals of old calves, SMO = separation meals of old calves, RST $=$ relative suckling time, Ejection $=\mathrm{AB}+\mathrm{CD}$, n. $\mathrm{s} .=$ not significant $(\mathrm{P} \geq 0.1)$.

The unforeseen long bouts during the $\mathrm{AB}$ of some meals mentioned above, revealed that eagerness of suckling cannot be measured by relative suckling time alone. In the main and in the additional control experiments eagerness of suckling was expressed as the arithmetic mean of non-suckling period per bout (referred to as "non-suckling") for the whole meal and each of the meal periods.

\section{Field Study}

Table 4 shows the LSM of the variables that had been significantly influenced by "age $\mathrm{x}$ type of access". Two voluntary meals of old calves had to be excluded because they showed no structure at all. The pattern of one of these meals is shown in Figure 3.

Relative suckling time increased in tendency (young calves) or significantly (old calves) in separation meals. Thus the field study seemingly supported the spontaneous impression of increased eagerness of separation meals. In principal, separation confounded with increasing lightness and/or man-made activities as external timers increased also length of meal, longest bout and the different periods within a meal. 
Bout, $\mathrm{s}$

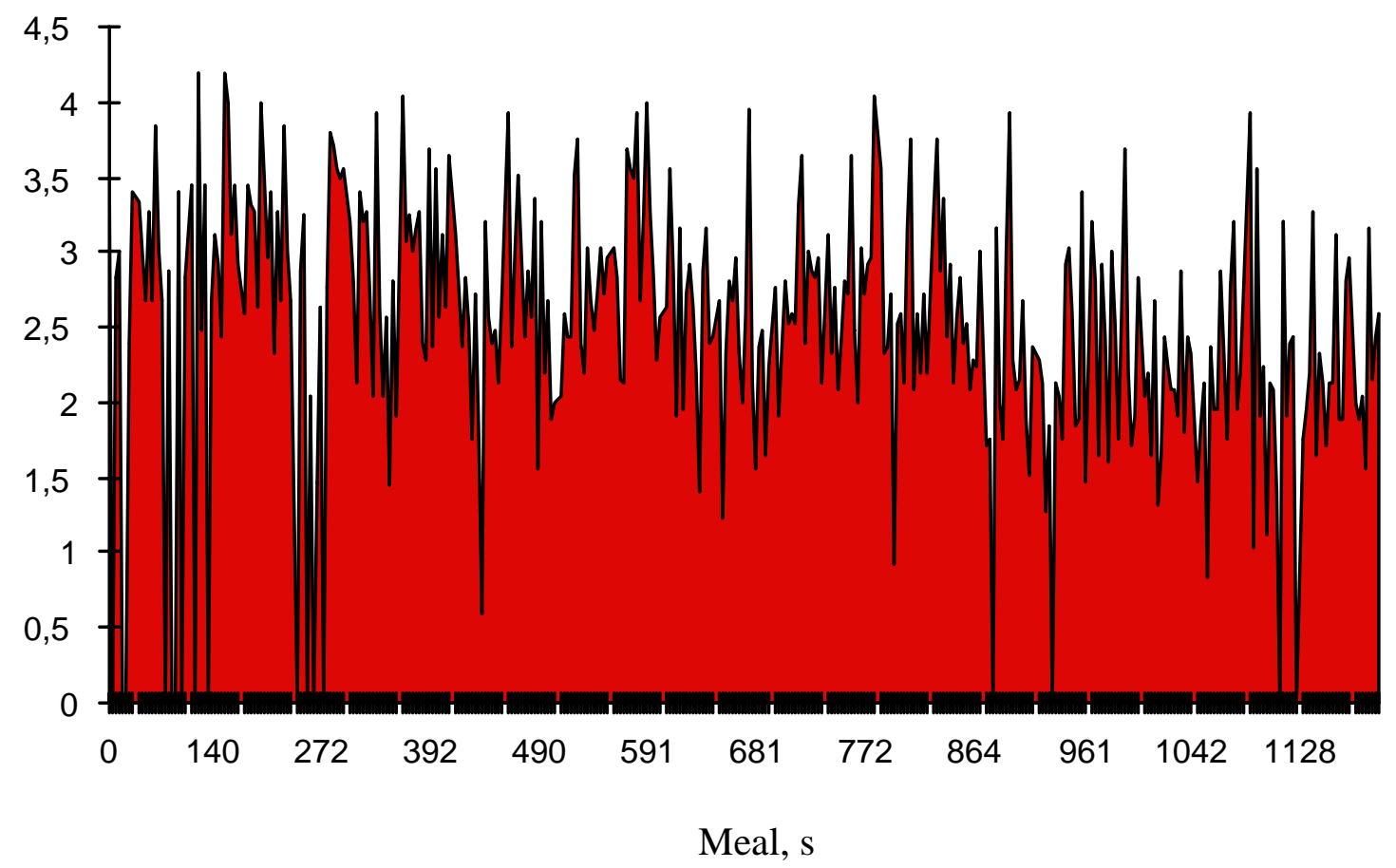

Fig. 3: Example of a voluntary suckling meal (169-day-old bull calf) without any structure (Beispiel eines spontanen Mahls eines 169 Tage alten Bullenkalbes ohne Struktur)

\section{Main Experiment}

The applied model resulted in $\mathrm{r}^{2}<0.4$ for relative suckling time and non-suckling during $\mathrm{CD}$. The analysis resulted in a non-significant $F$-value (0.29 and 0.67$)$ only for these two variables. Tables 5 to 9 show the contrasts between the least-square means of those variables, which were significantly influenced by treatment.

The results - cum grano salis - can be summarized as follows:

Milk withdrawal increased the length of meal and longest bout in accordance with the results of the field study. To ease reading we here show the comparisons behind the first part of that first statement: Compare in Table 5, second column: LSM $_{\mathrm{LM}}$ (leastsquare means of longest bout) of pure treatment of milk withdrawal vs control or Mrs vs mrs (=1316 > 765, $P<0.001$ ), MRs vs mRs (= 888 vs 774 , n.s.), MrS vs mrS (= 1301 vs 873 , n.s.), and MRS vs mRS $(=1063>694, P<0.01)$. The comparison including the pure treatment of milk withdrawal and control and two of the remaining comparisons showed significant and similar contrasts. Thus the second condition to assume a significant influence of milk withdrawal on the longest bout was fulfilled. Milk withdrawal did not influence the structure of meal except for a longer period of $\mathrm{BC}$, which more or less compensated for the decrease in $\mathrm{AB}$. The interpretation that milk withdrawal increased the periods of meal equivalent to the increased length of meal is confirmed by the results of $\mathrm{CD}$ and $\mathrm{DE}$. Milk withdrawal resulted in longer bouts during $\mathrm{AB}$ but had no significant influence on relative suckling time or nonsuckling. 
Table 5

Least-square means (LSM) and contrasts of length of meal (LM); longest bout (LB); relative suckling time (RST\%) and mean of non-suckling (MNS) for the whole meal and relative number of bouts within prestimulation (NBAB); m: no milk withdrawal, M: milk withdrawal, r: no suckling during stable routines, R: suckling during stable routines, s: no separation, S: separation (Least-square means (LSM) und Kontraste der Mahlzeitlänge (LM); des längsten Bout (LB); der relativen Saugezeit (RST\%) und der mittleren Nichtsaugezeit (MNS) für die ganze Mahlzeit und der relativen Boutzahl während der Vorstimulation (NBAB); m: kein Milchhunger, M: Milchhunger, r: kein Saugen während Stallroutinen, R: Saugen während Stallroutinen, s: kein Saugen nach Trennung von der Mutter, S: Saugen nach Trennung von der Mutter)

\begin{tabular}{|c|c|c|c|c|c|}
\hline Treatment & $\mathrm{LSM}_{\mathrm{LM}}$ & $\mathrm{LSM}_{\mathrm{LB}}$ & $\mathrm{LSM}_{\mathrm{RST}} \%$ & $\mathrm{LSM}_{\mathrm{MNS}}$ & $\mathrm{LSM}_{\mathrm{NBAB}}$ \\
\hline $\mathrm{mrs}$ & $765 \underline{\mathrm{ABC}}$ & $8.2 \mathrm{ABC}$ & $59.1 \mathrm{ABCD}$ & 1.50 AbCDEF & $0.36 \underline{\mathrm{A} b C D} \underline{\mathrm{DEF}}$ \\
\hline Mrs & $1316 \underline{\text { ADEFGhIj }}$ & 23.3 AdEf & 65.5 EFGH & $1.53 \mathrm{GHI}$ & $0.01 \underline{\mathrm{AGHI}} \mathrm{KK}$ \\
\hline $\mathrm{mRs}$ & $774 \underline{\mathrm{DK}}$ & $11.1 \mathrm{dGh}$ & $74.0 \mathrm{AE}$ & 1.17 AGJ & 0.27 bGLMNO \\
\hline $\mathrm{mrS}$ & $873 \bar{E}$ & 5.7 EiJK & $67.7 \mathrm{i}$ & 1.22 bK & $0.33 \underline{\mathrm{HP}} \underline{\mathrm{QR}} \overline{\mathrm{R}}$ \\
\hline MRs & $888 \underline{\mathrm{FL}}$ & $19.2 \mathrm{i}$ & $69.3 \mathrm{JK}$ & $1.29 \mathrm{Clm}$ & $0.12 \overline{C I L P}$ \\
\hline $\mathrm{MrS}$ & 1301 BIKLMn & 26.3 BGJLL & $70.9 \mathrm{BF}$ & $1.08 \mathrm{D}$ & 0.03 DMQtu \\
\hline mRS & $694 \overline{\mathrm{GMO}}$ & $10.3 \mathrm{fLM}$ & 77.0 CGJ & 0.89 EHJl & 0.09 EjNRt \\
\hline MRS & 1063 Chjno & $25.8 \mathrm{ChKM}$ & 76.3 DHiK & 0.88 FIKm & 0.11 FKOSu \\
\hline
\end{tabular}

A, B, c: similar underlined capitals differ $(P<0.001)$, similar capitals $(P<0.01)$, and similar lower cases $(P<0.05)$.

Table 6

Least-square means (LSM) and contrasts of absolute pre-stimulation (ABS); increasing ejection (BCS); declining ejection (CDS); after-stimulation (DES); m: no milk withdrawal, M: milk withdrawal, r: no suckling during stable routines, R: suckling during stable routines, s: no separation, S: separation (Least-square means (LSM) und Kontraste der absoluten Dauer von Vorstimulation (ABS); zunehmenden Ejektion (BCS); abnehmenden Ejektion (BD); Nachstimulation (DE); m: kein Milchhunger, M: Milchhunger, r: kein Saugen während Stallroutinen, R: Saugen während Stallroutinen, s: kein Saugen nach Trennung von der Mutter, S: Saugen nach Trennung von der Mutter)

\begin{tabular}{|c|c|c|c|c|}
\hline Treatment & $\mathrm{LSM}_{\mathrm{ABS}}$ & $\mathrm{LSM}_{\mathrm{BCS}}$ & $\mathrm{LSM}_{\mathrm{CDS}}$ & $\mathrm{LSM}_{\mathrm{DES}}$ \\
\hline mrs & $44.2 \mathrm{ABCD}$ & $45.6 \mathrm{aB}$ & $65.4 \mathrm{AB}$ & $610 \underline{\mathrm{AB}}$ \\
\hline Mrs & -8.1 AeFGH & $96.4 \mathrm{acD}$ & 183.3 AcDe & 1045 ACDEFG \\
\hline mRs & $31.1 \mathrm{ei} \underline{J}$ & $89.3 \mathrm{E}$ & 106.9 c & $547 \underline{\mathrm{CH}}$ \\
\hline $\mathrm{mrS}$ & 45.3 FKIM & $51.4 \mathrm{~F}$ & $75.0 \mathrm{DF}$ & $701 \mathrm{DI}$ \\
\hline MRs & $55.8 \underline{\text { GNOP }}$ & $40.5 \mathrm{c} \underline{\mathrm{G}}$ & 137.6 & $654 \underline{\mathrm{EJ}}$ \\
\hline $\mathrm{MrS}$ & $-3.5 \overline{\mathrm{BiKNQ}}$ & $138.6 \underline{\mathrm{BF}} \underline{\mathrm{G}} \mathrm{HI}$ & 116.1 & 1050 BHIJKL \\
\hline mRS & $6.4 \mathrm{clO} \underline{\mathrm{R}}$ & $63.5 \overline{\mathrm{Hj}}$ & $103.3 \mathrm{eg}$ & $521 \overline{\mathrm{FKm}}$ \\
\hline MRS & 121.0 DHJMPQR & 11.8 DEIj & 188.2 BFg & 742 GLm \\
\hline
\end{tabular}

$\underline{\mathrm{A}}, \mathrm{B}, \mathrm{c}$ : similar underlined capitals differ $(P<0.001)$, similar capitals $(P<0.01)$, and similar lower cases $(P<0.05)$.

Table 7

Least-square means (LSM) and contrasts of relative pre-stimulation (AB\%); increasing ejection (BC\%); declining ejection (CD\%); after-stimulation (DE\%); m: no milk withdrawal, M: milk withdrawal, r: no suckling during stable routines, R: suckling during stable routines, s: no separation, S: separation (Least-square means (LSM) und Kontraste der relativen Dauer von Vorstimulation (AB\%); zunehmender Ejektion (BC\%); abnehmender Ejektion (BD\%); Nachstimulation (DE\%); m: kein Milchhunger, M: Milchhunger, r: kein Saugen während Stallroutinen, R: Saugen während Stallroutinen, s: kein Saugen nach Trennung von der Mutter, S: Saugen nach Trennung von der Mutter)

\begin{tabular}{lllll}
\hline Treatment & $\mathrm{LSM}_{\mathrm{AB} \%}$ & $\mathrm{LSM}_{\mathrm{BC} \%}$ & $\mathrm{LSM}_{\mathrm{CD} \%}$ & $\mathrm{LSM}_{\mathrm{DE} \%}$ \\
\hline mrs & 6.0 & $5.5 \mathrm{a}$ & $11.0 \mathrm{a}$ & $77.5 \mathrm{a}$ \\
$\mathrm{Mrs}$ & $-0.5 \mathrm{ABC}$ & $7.3 \mathrm{~b}$ & 14.1 & $79.2 \mathrm{Bc}$ \\
$\mathrm{mRs}$ & $5.0 \underline{\mathrm{D}}$ & $12.0 \mathrm{acDE}$ & $16.2 \mathrm{~b}$ & $66.7 \mathrm{aBD}$ \\
$\mathrm{mrS}$ & $5.7 \mathrm{AEf}$ & $6.1 \mathrm{c}$ & $10.3 \mathrm{c}$ & $78.0 \mathrm{e}$ \\
$\mathrm{MRs}$ & $7.2 \underline{\mathrm{BG}}$ & $3.7 \mathrm{Df}$ & $17.1 \mathrm{D}$ & $72.0 \mathrm{f}$ \\
$\mathrm{MrS}$ & $-0.03 \mathrm{EGH}$ & $10.7 \mathrm{fG}$ & $7.7 \mathrm{bDEF}$ & $81.6 \underline{\mathrm{DfG}}$ \\
$\mathrm{mRS}$ & $1.8 \mathrm{fI}$ & $8.5 \mathrm{~h}$ & $18.6 \mathrm{acE}$ & 71.1 \\
MRS & $12.2 \underline{\mathrm{CDHI}}$ & $1.2 \mathrm{bEGh}$ & $17.3 \mathrm{~F}$ & $69.4 \mathrm{ceG}$ \\
\hline
\end{tabular}

$\underline{\mathrm{A}}, \mathrm{B}$, c: similar underlined capitals differ $(P<0.001)$, similar capitals $(P<0.01)$, and similar lower cases $(P<0.05)$. 
Table 8

Least-square means (LSM) of relative suckling time (RST\%) during pre-stimulation (AB), increasing ejection (BC), and after-stimulation (DE); m: no milk withdrawal, M: milk withdrawal, r: no suckling during stable routines, R: suckling during stable routines, s: no separation, S: separation (Least-square means (LSM) und Kontraste der absoluten Dauer von relativer Saugezeit (RST\%) während Vorstimulation (AB), zunehmender Ejektion (BC), abnehmender Ejektion (CD) und Nachstimulation (DE); m: kein Milchhunger, M: Milchhunger, r: kein Saugen während Stallroutinen, R: Saugen während Stallroutinen, s: kein Saugen nach Trennung von der Mutter, S: Saugen nach Trennung von der Mutter)

\begin{tabular}{|c|c|c|c|}
\hline Treatment & $\mathrm{LSM}_{\mathrm{RST} \% \mathrm{AB}}$ & $\mathrm{LSM}_{\mathrm{RST} \% \mathrm{BC}}$ & $\mathrm{LSM}_{\mathrm{RST} \% \mathrm{DE}}$ \\
\hline mrs & 55.1 AbCDEFG & 79.4 ABCDEF & $55.1 \mathrm{AbCD}$ \\
\hline Mrs & $86.0 \overline{\mathrm{A}} \overline{\mathrm{Hi}}$ & $92.1 \overline{\mathrm{AGH}}$ & $60.8 \mathrm{e}^{-}$ \\
\hline mRs & $66.8 \overline{\mathrm{bHJKLM}}$ & $85.5 \underline{\text { BGIJKL }}$ & $65.6 \mathrm{~A}$ \\
\hline $\mathrm{mrS}$ & 75.7 Ci№p & $87.0 \mathrm{Hm} \underline{\mathrm{N}} \mathrm{p} \underline{\mathrm{P}}$ & $61.5 \mathrm{f}$ \\
\hline MRs & $88.4 \underline{\mathrm{DJ}}$ & $90.7 \underline{\text { CIm }}$ & $60.0 \mathrm{~g}$ \\
\hline $\mathrm{MrS}$ & $92.6 \underline{\mathrm{EKN}}$ & 93.1 $\underline{\mathrm{DJN}}$ & $63.3 \mathrm{~b}$ \\
\hline mRS & $87.3 \overline{\text { FLo }}$ & $90.5 \overline{\mathrm{EKo}}$ & 71.2 Cefg \\
\hline MRS & $92.4 \overline{\mathrm{GMP}}$ & $93.1 \overline{F L P}$ & $67.8 \overline{\mathrm{D}}$ \\
\hline
\end{tabular}

$\underline{\mathrm{A}}, \mathrm{B}, \mathrm{c}$ : similar underlined capitals differ $(P<0.001)$, similar capitals $(P<0.01)$, and similar lower cases $(P<0.05)$

Stable routines had no influence on the length of meal or the longest bout, but increased pre- and decreased DE. They also resulted in longer bouts during AB. There was no conclusive effect on relative suckling time or on non-suckling either for the meal as a whole, or parts of it.

Separation did not influence length of meal, longest bout, structure of meal or length of bouts during $\mathrm{AB}$, but increased relative suckling time, and decreased non-suckling for the whole meal and during all periods, except for CD.

Table 9

Least-square means (LSM) of mean not-suckling (MNS) during pre-stimulation (AB), increasing ejection (BC), and after-stimulation (DE); m: no milk withdrawal, M: milk withdrawal, r: no suckling during stable routines, R: suckling during stable routines, s: no separation, S: separation (Least-square means (LSM) und Kontraste von mittlerer Nichtsaugezeit (MNS) während Vorstimulation (AB), zunehmender Ejektion (BC), abnehmender Ejektion (CD) und Nachstimulation (DE); m: kein Milchhunger, M: Milchhunger, r: kein Saugen während Stallroutinen, R: Saugen während Stallroutinen, s: kein Saugen nach Trennung von der Mutter, S: Saugen nach Trennung von der Mutter)

\begin{tabular}{llll}
\hline Treatment & LSM $_{\text {MNSAB }}$ & LSM $_{\text {MNSBC }}$ & LSM $_{\text {MNSDE }}$ \\
\hline mrs & $1.82 \mathrm{ABCDE}$ & $1.11 \mathrm{AbCDE}$ & $1.62 \mathrm{aBCD}$ \\
Mrs & $1.39 \mathrm{fGH}$ & $0.74 \mathrm{~A}$ & $1.63 \mathrm{eF} \underline{\mathrm{GH}}$ \\
$\mathrm{mRs}$ & $1.54 \mathrm{iJKL}$ & $0.99 \mathrm{FGH}$ & $1.25 \mathrm{aei}$ \\
$\mathrm{mrS}$ & $1.14 \mathrm{~A}$ & $0.87 \mathrm{ij}$ & $1.32 \mathrm{jk}$ \\
$\mathrm{MRs}$ & $1.02 \mathrm{Bi}$ & $0.84 \mathrm{bkl}$ & $1.38 \mathrm{Lm}$ \\
$\mathrm{MrS}$ & $0.78 \underline{\mathrm{CfJ}}$ & $0.55 \mathrm{CFik}$ & $1.13 \mathrm{BF}$ \\
$\mathrm{mRS}$ & $0.67 \underline{\mathrm{DGK}}$ & $0.64 \mathrm{DG}$ & $0.88 \mathrm{CG} \mathrm{jj}$ \\
MRS & $0.69 \underline{\mathrm{EHL}}$ & $0.53 \mathrm{EHjl}$ & $0.94 \underline{\mathrm{DH}} \mathrm{km}$ \\
\hline
\end{tabular}

A, B, c: similar underlined capitals differ $(P<0.001)$, similar capitals $(P<0.01)$, and similar lower cases $(P<0.05)$

\section{Additional Control Experiments}

Analysing the variables mentioned above in the control of control experiment resulted in a mean $\mathrm{r}^{2}$-value of 0.68 . After-stimulation $\%$ was shorter, and non-suckling during the whole meal was larger in control of control meals compared to the control meals of the main experiment. The same analysis for the control of type of separation experiment resulted in a mean $\mathrm{r}^{2}$-value of $0.61 . \mathrm{CD}_{\mathrm{s}}$ was longer; non-suckling during increasing and CD was larger in control of type of separation meals compared to meal after separation with remaining acoustic, visual or olfactory exchange. 


\section{Field Study}

\section{Discussion}

The limited numbers of replication, group composition confounded concerning age and sex as well as different further confounding (e.g., different times for announcing re-unification of calf and dam with age group) should prevent detailed interpretation of the results. The spontaneous impression that suckling during separation meals was carried out with intensified eagerness was seemingly supported by the differences shown for relative suckling time. However, this result could be misleading (see General discussion further down).

\section{Main Experiment}

MAYNTZ and COSTA (1998) showed that a calf optimises suckling by adopting length of bout to the milk available in the cistern (CROSS, 1977). Following this model we have to explain why there was milk in the cistern at the beginning of milk withdrawal meals and meals during stable routines (referred to as "stable routine meals").

Beef dams tolerant of milking would have been ideal for these experiments. However, some dams used did not belong to that category. Therefore, milk withdrawal meals were confounded with "udder not emptied during 18 hours". Even if you assume that the alveolar lumina (CROSS, 1977) could have stored all secreted milk during 18 hours, several conditioned ejections might have occurred due to external natural and man-made timers, e.g., increasing lightness at dawn, stable routines, and concentrate feeding (SVENNERSTEN et al., 1990), neighbouring calves suckling and - last but not least - habit induced by the uniformity of human routine. The presence of substantial amounts of milk in the cistern already before the onset of $A B$ was confirmed by the significantly longer bouts during $\mathrm{AB}$ of milk withdrawal meals (Fig. 2). This milk, available at the onset of a meal and, consequently, the long bouts during $A B$ sometimes made the determination of point $B$ (Fig. 1) extremely difficult. This difficulty is probably why changes in the neighbouring periods, $A B$ and $B C$, were compensatory in milk withdrawal meals and why clear effects of milk withdrawal on these periods could not be seen. Also, the increased longest bout - and all bouts during increasing and CD - can be explained by the fact that an ejection followed on top of the high amount of milk available at the onset of such a meal. If the harvest of that cistern milk did not result in an ejection, we would have seen a decrease of length of bouts until point D (Fig. 1). That, however, was not the case (Fig. 2). Therefore the use of the nomination "pre-stimulation" for phase $\mathrm{AB}$ is justified even for milk withdrawal and stable routine meals.

An un-confounded effect of milk withdrawal is seen in the prolongation of DE. There are several possible reasons for that: A calf desiring for milk (i) does want to ingest the last drops, (ii) is more responsive to the increasing fat content (JOHANSSON et al., 1952), (iii) finds it more self-rewarding to suckle and (iv) begs for more secretion (GODFRAY, 1995). We are critical of options (ii) and (iv), because there was not the slightest indication of a sensation for increased fat content (MAYNTZ, unpublished data), and because there is a high probability that DE (i.e., the harvest of after-rinsing parts of already ejected milk (MAYNTZ and COSTA, 1998)) is much less costly in Bos taurus than e.g., in Sus scrofa and therefore might not fulfil the basic condition for the honest begging signal. 
$\mathrm{AB}$ for stable routine meals looked somewhat similar to those for milk withdrawal meals. However, the increased bout-length during AB was not as large as for milk withdrawal meals. We would not expect milk in the cisterns prior to stable routine meals to be due to missed emptying, but we could expect some milk due to conditioned ejections and/or feeding of concentrates (SVENNERSTEN et al., 1990). A somewhat increased amount of milk available in the cistern shortly before an oxytocin related ejection could be interpreted as a separate and preceding stimulation of $\beta$ adrenergic receptors of the milk ducts (BRUCKMAIER 2005). Any timer or provision that affects the milk flow from the alveoli to the cistern will influence suckling behaviour as well.

The calves' eagerness to consume concentrates, which were available only during a short part of stable routine work, explains the significant decrease in DE in stable routine meals. This is even seen when stable routines and milk withdrawal are combined. This interpretation might be supported by the results in the field study: Concentrates were available for the old calves after separation meals, but not for the young calves.

Separation did not influence the meal as a whole or the structure of meal, not even when combined with milk withdrawal or stable routines. Thus, there is no indication that either form of the short dam-calf separation applied in the research reported here was stressful to the dam as far as it can be judged on the basis of the behavioural variables measured. Eagerness of suckling was substantially increased in separation meals. Calves, who had not been separated, often started a suckling meal by just sniffing and/or licking and/or slightly pushing the teats. They also made minor pauses during AB. Separated calves almost always immediately took teats into their mouth and sucked them throughout AB.

Concerning methodology, the results reported here are clear-cut. If you want to record meals that are representative of voluntary suckling behaviour of Bos taurus you may separate calf and dam only if (i) separation is so short that the calf does not experience desire for milk, (ii) no external timer or any other event influences the milk flow out of the capillary area during separation, (iii) the variables refer to the meal as a whole or structure of meal, and (iv) no food choice is offered to the calf after reunion. If, however, variables are related to eagerness of suckling, calf and dam should not be separated at all. These restrictions for the purpose of using a time-saving procedure may not be as detrimental as it seems because separating offspring and mother probably contributes more to the observer's comfort than to preventing idle time: A very large number of mammalian species - and Bos taurus for sure - show a certain suckling meal at dawn.

\section{Additional Control Experiments}

The two variables ( $\mathrm{DE}_{\%}$ and non-suckling ${ }_{\text {meal }}$ ), significantly differing between the control of control and the control meals applied of the main experiment - cum grano salis - do not reject the hypothesis that both control meals did not substantially differ from each other. Similarly, separation without acoustical, visual or olfactory exchange did not influence suckling behaviour in a way that it became substantially different from the behaviour during the separation meals in the main experiment.

\section{General Discussion}

It was not possible to prevent confounding of milk withdrawal with not emptied udder. 
However, the additional variable "relative number of bouts within $\mathrm{AB}$ " at least made it possible to demonstrate the differences between meals with and without long bouts during $\mathrm{AB}$. The long bouts during $\mathrm{AB}$ made the determination of point $\mathrm{B}$ very difficult. This is emphasized when $\mathrm{AB}$ and $\mathrm{BC}$ are summarized. In that analysis the treatment effect disappeared $\left(F_{7,63}=1.472 ; P=0.204\right.$ for $\mathrm{AB}_{\mathrm{s}}+\mathrm{BC}_{\mathrm{s}}$ and $F_{7,63}=$ 1.8703; $P=0.099$ for $\left.\mathrm{AB}_{\%}+\mathrm{BC}_{\%}\right)$. Thus, the analysis of the two initial periods of a meal might not be appropriate when larger amounts of milk are available in the cistern at the onset of a meal.

When bouts during $\mathrm{AB}$ become longer, the relative share of non-suckling activities must become smaller even if e.g., teat change is not carried out faster. Likewise must relative suckling time also increase when bouts during $\mathrm{AB}$ don't become longer but teat change is carried out faster. Thus, it could be misleading to assume increased eagerness on the basis of increased relative suckling time only.

An example of such misleading interpretation of relative suckling time can be seen in Tables 5, 8 and 9: The pure treatment of stable routine showed longer bouts during $\mathrm{AB}$ compared with control (Tab. 5: $\mathrm{LSM}_{\mathrm{NBAB}}$ of mRs vs mrs or 0.27 vs $0.36, P<0.05$ ). Consequently relative suckling time and thereby efficiency of suckling is increased during $\mathrm{AB}$ of pure treatment of stable routine too (Tab. 8: $\mathrm{LSM}_{\mathrm{RST}} \mathrm{AB}$ of mRs vs mrs or 66.8 vs 55.1, $P<0.05)$. However, assuming increased eagerness on the basis of the later result would probably be wrong because the change between teats was not carried out significantly faster (Tab. 9: LSM $_{\mathrm{MNSAB}}$ of $\mathrm{mRs}$ vs mrs or 1.54 vs 1.82, n.s.). Therefore we propose to judge eagerness of suckling on the basis of non-suckling, an appropriate and unbiased variable.

The data revealed a general pattern of non-suckling over a meal. It dropped from an $\mathrm{AB}$ value as soon as milk became available, i.e. at the onset of BC. Sometimes it started to increase again towards the end of CD, probably due to the increased number of udder pushes (HALEY et al., 1998) at the transition from CD to DE. Non-suckling gradually increased during $\mathrm{DE}$, sometimes dramatically when a calf took several longer breaks. This general pattern was observed irrespective of the initial and/or general level of non-suckling. This general level probably expressed the skill or temperament of the calf and was lower during separation meals. The pattern of nonsuckling also demonstrated that the best variables to evaluate the effect of any treatment on eagerness of suckling were non-suckling during $\mathrm{AB}$ and/or $\mathrm{BC}$ because the later irregular increase might blur the treatment effect.

The unexpected pattern from two voluntary meals by older calves (Fig. 3) is worth further discussion. Seen from the point of view that available milk and length of bout are closely related, no ejection (or only a minuscule one) seemed to have occurred during these meals. Their pattern is strikingly similar to those that resulted from a pharmacological blockage of oxytocin (MAYNTZ and COSTA, 1998). The fact that such voluntary meals could be observed in old calves initiates several reflections: These meals might indicate how suckling behaviour of calf and endocrinology of dam are linked during natural weaning in Bos taurus. They further raise the question whether suckling per se in Bos taurus might show spontaneity as described in the Lorenzian model (LORENZ, 1981).

The close relationship between length of bout and the amount of milk available in the cistern, confirmed in the main experiment, is a stereotypical reaction, which is similar to the reaction towards artificial teats described by RUSHEN and de PASSILLÉ 
(1995). However, to asses the value of harvesting additional after-rinsing drops against the chance to consume concentrates and the clear effect of separation on the eagerness with which suckling is carried out indicates that the calf's behaviour might be as poor or as rich as the actual environment.

\section{Acknowledgements}

The authors wish to thank the staff of the Wielki Las experimental station of the Polish Academy of Science and the Hellner family for granting access to their animals and practical help during the experiments. We also thank Prof. em. W. G. Merrill, Adam Goodchild, and Faye Fairholm-Heinonen for valuable comments and help with English.

\section{References}

BOONBRAHM, N., PETERS, K.J.; INTISANG, W.:

The influence of calf rearing methods and milking methods on performance traits of crossbred dairy cattle in Thailand. III. Calf performance. Arch. Tierz., Dummerstorf 47 (2004), 405-414

BRUCKMAIER, R.M.:

The importance of adrenergic receptors in the bovine udder for milk removal. (V TANCIN, S MIHINA, M UHRINCAT, M Eds.) Proceedings of the International Conerence Physiological and Technical Aspects of Machine Milking, Nitra, Slovak Republic (2005), 9-14

CASTRO, W.L.R., MATT, K.S.:

Neuroendocrine correlates of separation stress in the siberian Dwarf Hamster (Phodopus sungorus). Physiol. Behav. 61 (1997), 477-484

COCHRAN, W.G., COX, G.M.:

Experimental Designs. Second ed. John Wiley and Sons, New York, London (1957), 125-126

CROSS, B.A.:

Comparative physiology of milk removal. Symp. zool. Soc. London. 41 (1977), 193-210

De PASSILLÉ, A.M., METZ, J.H.M., MEKKING, P., WIEPKEMA, P.R.: Does drinking milk stimulate sucking in young calves? Appl. Anim. Behav. Sci. 34 (1992), 23-36

GODFRAY, H.C.J.:

Signalling of need between parents and young: Parent-offspring conflict and sibling rivalry. Am. Nat. 146 (1995), 1-24

HALL, W.G., HUDSON, R., BRAKE, S.C.:

Terminology for use in investigations of nursing and suckling. Dev. Psychobiol. 21 (1988), 89-91

HALEY, D.B., RUSHEN, J., DUNCAN, I.J.H., WIDOWSKI, T.M., de PASSILLÉ, A.M.: Butting by calves, Bos taurus, and rate of milk flow. Anim. Behav. 56 (1998), 1545-1551

HORRELL, I.:

Suckling tactics in multiple-suckling calves. (MM NICHELMANN, H.K. WIERENGA, S BRAUN, Eds.) Proceedings 27th International Congress Applied Ethology, Berlin, FRG, (1993), 201-205

JOHANSSON, I., KORLMAN, N., NELSON, N.J.:

Studies on udder evacuation in dairy cows. I. The rise in fat percentage during milking. Acta Agric. Scand. 2 (1952), 43-81

LORENZ, K.:

The Foundations of Ethology. Springer, New York (1981), 118-125

MANTEUFFEL, G.:

Central nervous regulation of the hypothalamic-pituitary-adrenal axis and its impact on fertility, immunity, metabolism and animal welfare - a review. Arch. Tierz., Dummerstorf 45 (2002) , 575-595

MAYNTZ, M., COSTA, R.:

Effect of pharmacologically induced changes in milk ejection on suckling in Bos taurus. Physiol. Behav. 65 (1998), 151-156

MIELKE, H.:

Neue Ergebnisse der Untersuchungen über Milchejektionshemmung. Mh. Vet. med. 36 (1981), 525-530

RUSHEN, J., de PASSILLÉ, A.M.:

The motivation of non-nutritive suckling in calves, Bos taurus. Anim. Behav. 49 (1995), 1503-1510

SANDOVAL, C., LEAVER, J.D.:

Effect of restricted suckling patterns on milk yield, milk composition and calf growth. J. Anim. Sci. 60 
(1995), 551

SAS/STAT:

User's Guide. Version 6, NC, SAS Institute Inc., Carry (1989), 549-640

SVENNERSTEN, K., NELSON, L., UVNÄS-MOBERG, K.:

Feeding induced oxytocin release in dairy cows. Acta Physiol. Scand. 140 (1990), 295-296

TEELUCK, J.P., HULMAN, B., PRESTON, T.R.:

Effect of milking frequency in combination with restricted suckling on milk yield and calf performance. Trop. Anim. Prod. 6 (1981), 138-145

THOMAS, G.W., SPIKER, S.A., MICKAN, F.J.:

Influence of suckling by Frisian cows on milk production and anoestrus. Aust. J. Exp. Anim. Husb. 21 (1981), 5-11

WEINER, H.:

Perturbing the Organism. University Press, Chicago, London (1992), 154

Received: 2005-12-15

Accepted: 2006-04-11

Authors' addresses

Dr. MICHAEL MAYNTZ*

Sofieberg

S-153 92 HÖLÖ, SWEDEN

E-Mail: michaelm@bahnhof.se

GRAZYNA SENDER, PhD, Docent. Institute of Genetics and Animal Breeding,

Polish Academy of Science,

PL-05-552 WÓLA KOSSOWSKA, POLAND

ANNELIE ANDERSSON, Mag. Phil., ROGER SEDERSTRÖM, Mag. Phil.

Department of Biology, IFM, University of Linköping,

SE-581 83 LINKÖPING, SWEDEN

*Corresponding Author 